\title{
THE LITTLEST REBEL: JAMES J. KILPATRICK AND THE SECOND CIVIL WAR
}

\author{
Garrett Epps*
}

In 1955 and 1956, James Jackson Kilpatrick, the 35-year-old editor of The Richmond News Leader, began a singleminded, and successful, crusade to transform the evolving regional debate about how the South should respond to the Supreme Court's decision in The School Segregation Cases. 1 Of the possible responses, Kilpatrick advocated one of the most extreme: the "interposition" of state power to defy the court and thwart the implementation of its order. He revived, elaborated, and publicized an intricate set of constitutional arguments that purported to demonstrate that any state in disagreement with a Court decision had the legal right to block it, and further argued that the South might, by adopting his plan, be able to prevent school desegregation permanently. Kilpatrick's arguments had a major impact on the regional response to Brown.

This article is not concerned with the racist ideology of segregation - though in that field, too, Kilpatrick made a major contribution. 2 And the article is only peripherally concerned with the anguished, and often sincere, arguments constructed by white Southern conservatives that Brown itself was wrongly decided. Instead, the article is concerned with the specific constitutional arguments-borrowed from the far fringes of the Southern right and moved by Kilpatrick's patronage into the Southern white mainstream-that purported to justify segregationist politicians' use of the power of state government to frustrate the implementation of Brown.

There are a number of reasons why this inquiry is worthwhile.

* B.A. Harvard College, 1972; M.A, Hollins College, 1975; J.D., Duke Law School; Assistant Professor, University of Oregon School of Law. The author would like to thank Walter Dellinger, William A. Van Alstyne and James O'Fallon for their generous assistance with earlier drafts of this article.

1. 347 U.S. 483 (1954), 349 U.S. 294 (1955).

2. See generally James Jackson Kilpatrick, The Southern Case for School Segregation (Crowell-Collier Press, 1962) ("Southern Case"), and I. A. Newby, Challenge to the Court: Social Scientists and the Defense of Segregation, 1954-1966 170-73 (La. St. U. Press, 1967) ("Challenge to the Court"). See also notes 66-70 below and accompanying text. 
The intellectual, political and social history of the segregated period has been sketchily and poorly written. Much of what is available is incomplete and distorted. Nor are all the distortions inadvertent. Former segregationists have a vested interest in downplaying the severity of Southern apartheid and in obscuring their own role in its maintenance. Indeed, like post Communist Russia, the desegregated South teems with "moderates" eager to establish their own long-standing, if often remarkably discreet, abhorrence of injustice. Kilpatrick himself is not above donning such scalawag garb. In his incarnation as a nationally syndicated newspaper columnist, Kilpatrick often explicitly denies his own past as a segregationist and constitutional radical. His standard rhetorical strategy in his contemporary guerrilla struggle against Brown and its progeny is to denounce new judicial or legislative extensions of civil rights guarantees for blacks by stating that he, Kilpatrick, has until now been a firm supporter of civil rights measures, but that this decision or bill finally goes too far. ${ }^{3}$

Further, it can be argued that the study of these ideas can help re-establish some intellectual accountability. Few journalists have displayed what might be called "gavel envy" more nakedly than Kilpatrick, who intersperses his columns with legal jargon and refers to his fellow columnists, like a common law judge, as "my brethren." Kilpatrick likes to write about the (post-Brown) Constitution as if he were both an authority on its meaning and an avatar of its values. It seems important that those who fought against the Constitution not be permitted without some examination to clothe themselves retroactively as its defenders.

There is a second, broader reason why a study of these constitutional arguments may be worthwhile. By peering at the dim fringes of constitutional debate, we may gain valuable insight into the national psyche. Organized intellectual opposition to the Con-

3. Compare, e.g., James J. Kilpatrick, "Judicial redistricting carries Voting Rights Act too far," The News and Observer (Raleigh, N.C.), December 7, 1988, at 15A ("I ardently supported [the Voting Rights Act of 1965] because I knew, as only a white Southerner can know, what chicanery my people had employed to prevent blacks from voting.") with James Jackson Kilpatrick, Must We Repeal the Constitution to Give the Negro the Vote?, in National Review 319 (April 20, 1965) (Proposed Voting Rights Act of 1965 "strikes with the brute and clumsy force of a wrecking ball at the very foundations of American federalism.").

In a recent column, Kilpatrick took a sternly antiracist tone with advocates of remedial measures to help minorities: "I worry about racial tensions, and I worry that all the posturing gestures of 'diversity' and 'multiculturalism' and 'affirmative action' are making bad matters worse. Our country ideally should be colorblind. We have become color obsessed." James Kilpatrick, Columnist's (Kind of) Farewell, The Register-Guard (Eugene, Ore.), Jan. 3, 1993, at B2 (emphasis added). Kilpatrick now writes a weekly column about the Supreme Court, which "has been the love of my newspaper life since I first visited the court in 1941." Id. For an earlier view of multiculturalism by Kilpatrick, see note 68 , below, and accompanying text. 
stitution collapsed after the Civil War. Before then, both secessionists and abolitionists questioned the presuppositions and formal prescriptions of the document. The bloody victory of the Union did more than establish that Constitution was unbreakable-it also made it unquestionable. 4

Since then, even the most radical social critics have tended to clothe their dissent in the language of loyalty to the Constitution, in effect attempting to destroy the existing constitutional order in the name of a higher loyalty to the Constitution. Their arguments form, in the Jungian sense of the term, the shadow of our political order-the remains of the urges, both destructive and creative, that must be repressed and denied as a price for the creation of social order and civilization. In a nation, as in an individual, the shadow is both powerful and hard to discern. In many ways it is as important a part of the society's political and legal personality as the more patent parts. ${ }^{5}$

In the immediate post-Brown era, Kilpatrick personified the national shadow. Examining his crusade against Brown can help illuminate the dark corners of our constitutional psyche. History will make the final judgment on the actions of James Jackson Kilpatrick in the moment of crisis, when he attempted to turn his pen into a gavel.

Kilpatrick has identified himself as a Virginia Conservative, but he was born in 1920 in Oklahoma City and has no significant Virginia roots. His original upbringing was in Oklahoma, with occasional trips to visit relatives in Louisiana. ${ }^{6}$

Kilpatrick graduated from the University of Missouri in 1941 with a degree in journalism and came to work at The Richmond

4. See Owen M. Fiss, Objectivity and Interpretation, 34 Stan. L. Rev. 739 (1982), reprinted in Sanford Levinson and Steven Mailloux, eds., Interpreting Law and Literature: $A$ Hermeneutic Reader 229, 237 (Nw. U. Press, 1988) ("[T]o dispute the authority of the Constitution . . . is a task not lightly engaged."); see also Garrett Epps, Politics as Metaphor, The Virginia Quarterly Review 75 (Winter 1979) (describing Constitution as supreme political fact that requires discussion of radical change in political fiction to take place in exclusively metaphoric terms).

5. See Jolande Jacobi, The Psychology of C.J. Jung 106-10 (Yale U. Press, 6th ed. 1961); Henri F. Ellenberger, The Discovery of the Unconscious: The History and Evolution of Dynamic Psychiatry 707 (Basic Books, 1970); Daryl Sharp, Jung Lexicon: A Primer of Terms and Concepts 123-25 (Inner City Books, 1991) ("Jung Lexicon"). Jung believed that the shadow was the source of much of a personality's energy. Sharp, Jung Lexicon at 125 . The same may be true of societies as a whole. An argument can be made that an important force in energizing American political life has been the process by which apparently anti-constitutional ideas have emerged from the Constitution's shadow and been, often after great strug. gle, incorporated into a transformed constitutional structure.

6. For biographical details, see generally Philip J. Hilts, The Retreat of James J. Kilpatrick, reprinted in Biography News 57 (Gale Research, 1974) ("Retreat") and Current Biography Yearbook 1980184 (H.W. Wilson, 1980). 
News Leader, an influential and highly conservative afternoon daily in the old Confederate capital. Charles Houston, a columnist for the News Leader, later told an interviewer, "When he arrived, he was rather on the liberal side. . . But he found out we were conservative, and learned quickly which side the bread was buttered on."7

Adopted as a protege by News Leader editor Douglas Southall Freeman, Kilpatrick was moved to the editorial page, and in 1949 succeeded Freeman as chief editorial writer, gaining the title of editor in 1951. Though energetic and talented, Kilpatrick might have remained an obscure figure on a small provincial daily. But history had put this young, ambitious, conservative segregationist in a position to play a leading role in the civil rights struggle. The moral ambiguities and enormous stakes of that struggle induced self-doubt in some of the South's white intelligentsia. But throughout the struggle, from 1954 until the assassination of Martin Luther King in 1968 and beyond, Kilpatrick never wavered in his hostility to civil rights, nor in his seeming certainty that the Southern cause was just. And his own certainty inspired others, more powerful than he, to take actions that put the Constitution itself at risk.

One historian of the period recalls the young editor's initial reaction to Brown: "The News Leader, which greeted the Supreme Court ruling of May, 1954, with a conciliatory editorial and a suggested program of compliance, had changed quickly to an attitude of fierce hostility. By October, 1955, it had become probably the most resounding voice of resistance in the Southern press."8

In his defiance, Kilpatrick turned to the idea of "interposition" as a strategy of resistance. Georgia Senator Herman Talmadge had been the first in the postwar period to suggest that the South resurrect the antebellum strategy of "interposing" state authority to block federal civil rights measures. His suggestion came three years before Brown. 9 Then, after the Brown decision, a Virginia lawyer named William Old privately printed a pamphlet advocating interposition to block its implementation. 10 The pamphlet came to Kilpatrick's attention, and Kilpatrick borrowed and refined the doctrine."11 Adopting it as News Leader policy, he conducted a re-

7. Hilts, Retreat at 58 (cited in note 6). "Mike" Houston (as he was named in the article) wrote under the byline Charles Houston for the News Leader.

8. Benjamin Muse, Virginia's Massive Resistance 20 (Ind. U. Press, 1961).

9. Numan V. Bartley, The Rise of Massive Resistance 128-29 (La. St. U. Press, 1969).

10. William Old, The Segregation Issue: Suggestions Regarding the Maintenance of State Autonomy (1955). Old, whose name is often plausibly but erroneously rendered by historians as "Olds," was later elevated to Virginia's Circuit bench.

11. Robbins L. Gates, The Making of Massive Resistance: Virginia's Politics of Public School Desegregation, 1954-1956 104 (U. of N.C. Press, 1964) ("Making of Resistance"). 
markable ideological blitzkrieg in the paper's pages that transformed the halting political dialogue in Virginia and across the South.

Kilpatrick's editorial campaign lasted from November 21, 1955, until February 2, 1956.12 Day after day, the News Leader editorial page carried essays on the legality, desirability and morality of interposing state authority between the Supreme Court and Southern schools, side-by-side with historic documents such as the Virginia and Kentucky Resolutions of 1798 and John C. Calhoun's Fort Hill Address.

Historian Numan Bartley has called this remarkable offensive "one of southern journalism's more successful editorial crusades." 13 Kilpatrick's crusade succeeded in transforming the political landscape not only of Virginia but of the South. Virginia's legislature, at the determined prodding of the News Leader, 14 rejected more moderate modes of resistance and began the era of "Massive Resistance" by passing a "Resolution of Interposition" on February 1, 1956. This document, which looks suspiciously similar to one submitted by Kilpatrick himself, 15 committed the state to using "all appropriate measures, legally and constitutionally available to us, to resist this illegal encroachment upon our sovereign powers and to urge upon our sister states ... their prompt and deliberate efforts to check this and further encroachment by the Supreme Court . . . upon the reserved powers of the states." 16

By itself, the Resolution was of little effect. 17 But the acceptance of interposition as the legal foundation of a strategy of massive resistance was immediate and widespread. Senator Harry F. Byrd, Sr., the undisputed leader of Virginia's political organization, hailed the doctrine of interposition as "a perfectly legal means of appeal from the Supreme Court's order" that could be the basis for an at-

12. The major editorials have been collected in Interposition: Editorials and Editorial Page Presentations, The Richmond News Leader, 1955-1956 (1956) ("Interposition").

13. Bartley, The Rise of Massive Resistance at 129 (cited in note 9).

14. See, e.g., Time to Fight it Out, The Richmond News Leader, January 23, 1956, reprinted in Interposition at 42 (cited in note 12): "[Q]uerulous little voices piping on Richmond's Capital Hill . . . complaining that, oh, the Supreme Court's decision in the school cases was dead wrong, but what would Chief Justice Warren say about 'interposition' " must realize that "the hour has come to stand up and be counted. . . God, give us men! We resist now, or we resist never. We surrender to the court effective control over our reserved powers, or we make a fight to preserve these powers. We lie down, piteous and pusillanimous, or we make a stand." (Emphasis in original).

15. Muse, Virginia's Massive Resistance at 21 (cited in note 8).

16. Id. at 22 .

17. See Gates, Making of Resistance at 116 (cited in note 11) (Remarks of Delegate Robert Whitehead: "The thunder roared, the lightning flashed and struck and a chigger was killed."). 
tempt to "organize the Southern States for massive resistance. ..."18 Byrd remarked on the floor of the United States Senate that "Mr. Kilpatrick has presented a fine service to the State of Virginia. ..."19 By passing the resolution, "Virginia offered leadership to the peripheral South in a program of massive resistance based upon the doctrine of interposition and, at the same time, provided states of the Deep South with a theoretical basis for opposition to desegregation." 20

Other state legislatures quickly responded with their own interposition measures, and in time, the entire South gave its support to the doctrine, though most did not follow Virginia into "massive resistance."21 Mississippi Governor James P. Coleman and South Carolina Governor George Bell Timmerman made a pilgrimage to Virginia to endorse interposition, while Georgia Governor S. Marvin Griffin, also at the meeting, called not only for interposition but outright nullification of Brown.22

And in Congress, supporters of interposition provided the motivating force behind the "Declaration of Constitutional Principles" that became known as the "Southern Manifesto," 23 although backstage compromises designed to win over "moderate" congressmen resulted in the deletion of interposition language from the final document. 24

The "appropriate means" adopted by Virginia in a special legislative session later in 1956 was a program by which the state government would take control of any local school system ordered to desegregate. Once under state control, the schools would be closed. The orders of the federal courts would be blocked by interposed

18. Muse, Virginia's Massive Resistance at 22 (cited in note 8).

19. Id. at 21 .

20. Bartley, The Rise of Massive Resistance at 134 (cited in note 9).

21. Id. at 135-44. See also W. D. Workman, Jr., The Deep South, in Don Shoemaker, ed., With All Deliberate Speed: Segregation-Desegregation in Southern Schools 88, 101 (Harper \& Brothers, 1957): "Within 18 months after Kilpatrick had launched his editorial campaign, all eight states of the Deep South (as well as others elsewhere) had adopted some form of what had come to be known as 'resolutions of interposition or protest."

22. Id. at 136-37. It was probably at this meeting that Robert B. Crawford, a Prince Edward County laundry owner who had become influential as president of the ultra-segregationist Defenders of State Sovereignty and Individual Liberties, introduced Kilpatrick to the group of governors. "You would have thought that Robert E. Lee had entered the room." Gates, Making of Resistance at 162 (cited in note 11). Georgia Governor Griffin's trip to Little Rock to advocate resistance was a key factor in the escalation of the Little Rock school crisis there, putting pressure on Arkansas Governor Orval Faubus to defy Federal authority. See Tony Freyer, The Little Rock Crisis: A Constitutional Interpretation 100 (Greenwood Press, 1984) ("The Little Rock Crisis").

23. Declaration of Constitutional Principles, 84th Cong., 2d Sess. (March 12, 1956) in 102 Cong. Rec. 4459-64, 4515-16.

24. Bartley, The Rise of Massive Resistance at 116-17 (cited in note 9). 
state authority. Any private lawsuit to challenge the closure could only be brought against the state itself, and the state refused the consent to be sued required under the Eleventh Amendment. In addition, any school district that might voluntarily attempt to desegregate without a court order would face a mandated cutoff of state funds. 25

Kilpatrick had provided the intellectual foundation for massive resistance. But his participation went well beyond the usual limits accepted by most journalists, even ideologically committed ones. He became an adviser to Governor Thomas Stanley ${ }^{26}$ and, while continuing his editorship of the News Leader, accepted the post of Publications Chairman of a new state government agency, the Virginia Commission on Constitutional Government, whose pro-interposition and anti-Brown pamphlets and press releases made it the "most consistently energetic [of all Southern state pro-segregation publicity bureaus] in propaganda and lobbying activity during the massive resistance phase of southern race politics." 27

After the special legislative session of 1956, Virginia's state government intervened and ordered the closing of schools in Warren County, Charlottesville and Norfolk. The actual closure of schools produced educational disruption among white students as well as blacks, and generated pressure from parents and business executives for the abandonment of the policy.28 But Virginia's wrenching experiment in interposition continued until 1959. On January 19 of that year, Robert E. Lee's 152nd birthday, the Virginia Supreme Court of Appeals 29 and a three-judge federal district court ${ }^{30}$ summarily invalidated the complex structure of fund-cutoff and school-closing laws that had been erected on Kilpatrick's ideological foundation. As enacted by the Virginia General Assembly, it turned out, "interposition" violated not only the U.S. Constitution, but the Virginia Constitution as well.

The era of "Massive Resistance" formally ended on January 28, 1959, when Virginia Governor Lindsay Almond, who had first roared defiance at the courts' adverse judgments, recommended to a special legislative session that milder forms of resistance be adopted. But most authorities believe that the death knell of "Massive Resist-

25. Bartley, The Rise of Massive Resistance at 113-14 (cited in note 9); Muse, Virginia's Massive Resistance at 28-34 (cited in note 8); Education: Public Schools-Virginia 1 Race Relations L. Rptr. 1091, $1091-1113$ (1956); Litigation: Virginia 2 Race Relations L. Rptr. 1015, 1015-26 (1957).

26. Gates, Making of Resistance at 110 (cited in note 11).

27. Bartley, The Rise of Massive Resistance at 183 (footnote omitted) (cited in note 9).

28. Muse, Virginia's Massive Resistance at 76-79, 86-94 (cited in note 8).

29. Harrison v. Day, 106 S.E.2d 636 (Va., 1959).

30. James v. Almond, 170 F.Supp. 331 (E.D. Va., 1959). 
ance" had been sounded earlier, in a speech to the Richmond Rotary Club on November 11, 1958, by a leader more important than Governor Almond. The local press covered this address in its news columns, as it might cover any address by an important politician or government official. The speaker predicted that the courts would invalidate Virginia's "Massive Resistance" laws and regretfully foresaw that "some public schools in Virginia ultimately may be coerced into some degree of integration." He presented a program to cope with the new situation, including laws that would permit localities threatened with court-ordered desegregation to close their own schools rather than mix the races. 31

The local-option school-closure plan, of course, would be followed to its tragic denouement in Prince Edward County, Virginia. The speaker who announced the next phase of Virginia's new Lost Cause was its leading tactician, indeed, perhaps its General George Pickett—James J. Kilpatrick. ${ }^{32}$

In the long saga of Southern resistance, Virginia's attempt to thwart the Court occupies a curious pride of place. Virginia's "Massive Resistance" was not violent, as in Mississippi and Alabama. Indeed, with its appeal to the Founders, it was oddly decorous, almost prim. But it was also far more adamant and more complete than that of other border states. And it was an important inspiration to the bitterest of resisters.

Jack Kilpatrick monkishly poring over parchment, and Virginia squires debating Locke and Hobbes, may seem far removed from fiery crosses, bombs and the segregationist mobs around Little Rock's Central High School. But as conservatives seldom tire of saying, ideas have consequences, and Kilpatrick's had many malign effects. Some believe that the South's most disgraceful episode of defiance, the Little Rock Crisis of 1957, had its inception in the solemn enthymemes that flowed from Kilpatrick's pen:

The mental processes of Governor Orval Faubus are difficult to fathom, but there are many in his state of Arkansas who believe that the events leading to the tragic convulsions of Little Rock would not have occurred had it not been for the example of apparent defiance of federal authority set by the conservative and

31. Muse, Virginia's Massive Resistance at 97 (cited in note 8).

32. For details of local school closure, see generally Bob Smith, They Closed Their Schools: Prince Edward County, 1951-1964 (U. of N.C. Press, 1965). Of particular interest is the discussion of Kilpatrick's role as patron and protector of the infant Prince Edward Academy, a private school formed to educate the county's white students (blacks were given no formal education for the five years of the closure). "Editor Kilpatrick . . . donated some eighty books [to the Academy's library]. To a considerable extent through his efforts, in a concentrated drive, the library was brought up to accreditation." Id. at 166-67. 
respected leaders of the Old Dominion. ${ }^{33}$

Virginia's attitude, so heavily influenced by Kilpatrick, set the tone for the whole South: "[A] constructive attitude [even though short of compliance] on the part of Virginia's leaders in the relatively propitious atmosphere of 1954-1955 might have changed the course of Southern history." 34

Thus, although Kilpatrick's attempt to thwart integration ultimately failed, it had a significant effect in the immediate post-Brown period. It is therefore worth examining his arguments in some detail. What was the Constitutional doctrine that Kilpatrick was so determined to impose on Virginia and, if possible, the rest of the nation, and what would have been the implications had it met with more widespread acceptance?

There are two main sources for divining Kilpatrick's Constitutional jurisprudence. The first is the series of editorials that appeared in the News Leader in late 1955 and early 1956, which were collected proudly by his employers for mass distribution across the South at the price of twenty-five cents a copy. ${ }^{35}$ Here we find the doctrine in its freshest form. Second is The Sovereign States, an ambitious book Kilpatrick published in 1957 in which he attempted nothing less than an historical overview and reinterpretation of the constitutional relationships of the states and the federal government. ${ }^{36}$ follows.

A definition gleaned from his writings might be expressed as

First, when in the view of state governments the federal government has overstepped its powers, state governments have the "right to interpose their sovereignty between the Federal Government and the object of its encroachments upon powers reserved to the States." 37

Second, the interposition of sovereignty may legally move beyond protest to "litigation, legislation, appeals to sisters States [sic] for Constitutional amendment, judicial proceedings within our

33. Muse, Virginia's Massive Resistance at 172 (cited in note 8). The major ideologist of white resistance in Arkansas was James Johnson, whose outspoken opposition to court-ordered desegregation helped prod Faubus into defiance. See Freyer, The Little Rock Crisis 6882 (cited in note 22). Johnson was an advocate of interposition, a doctrine he first learned of by reading Kilpatrick's editorials in the News Leader. Id. at 70.

34. Muse, Virginia's Massive Resistance at 176 (cited in note 8).

35. Interposition (cited in note 12).

36. James Jackson Kilpatrick, The Sovereign States: Notes of a Citizen of Virginia (Henry Regnery Co., 1957) ("Sovereign States"). Kilpatrick, a native of Oklahoma, had presumably acquired his Virginia citizenship under the terms of the Fourteenth Amendment.

37. Interposition at 16 (cited in note 12). 
State courts, and every other tactic . . . calculated 'to impede' enforcement of the court's decrees." 38

Third, outright defiance of the federal courts is a permissible action of a state that has interposed its authority: "[A] State, or a group of States, may defy the court on one question and remain wholly obedient to its orders on every other, the while remaining in the Union." 39

Lastly, when by interposition and outright defiance a state has created a constitutional impasse, the standoff may be resolved by an appeal, not to any court, but to the other states. The mechanism of decision would be a proposed Constitutional amendment declaring the interposing state's position incorrect. If three-fourths of the states refuse to ratify such an amendment, the state's stand would succeed and the federal government would be required to retire from the field. 40

It is, to contemporary eyes at least, a strange doctrine. Kilpatrick was at pains to claim deep historical roots for it-to insist, like a justice of the common law, that he was not creating doctrine but simply finding it. However, in its finished form, Kilpatrick's doctrine of interposition was his own creation, containing features never displayed before, and adapted with remarkable convenience to the expediency of the political struggle in which the white segregated South was fighting for its life.

In his book-length exposition, Kilpatrick frankly admitted that his view of the Constitution would overthrow the constitutional order that began with McCulloch v. Maryland: "The political heirs of Alexander Hamilton and John Marshall will not care much for [this book]."41

Kilpatrick's constitutional jurisprudence is based on the "compact theory" of the Constitution-the idea that the federal government is a pure creature of the states and that, though they may suffer it to exist while it serves their interests, all real sovereignty remains with the States and may be reclaimed by them at any moment.

38. Id. at $\mathbf{4 5}$.

39. Id. at 11 .

40. Id. at 18 .

41. Kilpatrick, Sovereign States at xi (cited in note 36). I suggest that this level of presumption - the suggestion that in some mystical way one is reclaiming the Constitution from everyone legally charged with interpreting it since the dawn of history-should alert any reader that we have entered the dreamlike realm of the constitutional shadow, where the "real" document is defended from political institutions, from history, and often-as in this case-from its own structure and provisions. For a contemporary example of this type of shadow argument, see generally Robert $\mathbf{H}$. Bork, The Tempting of America: The Political Seduction of The Law (The Free Press, 1990). 
The right to delegate powers to the Federal government, or to reserve them to the States, lies solely with the people of the several States.

This is the basis of our sovereignty, unchanged by John Marshall, unchanged by the Civil War, not altered in any way since the Constitution was created in 1787.42

Kilpatrick's search for the "real Constitution," embodying this model, began with documents written before its adoption. First, he argued, the Declaration of Independence ("too much recited and too little read") 43 was a document created by and expressing the will of the states only: it was signed by representatives of the states and in the name of the states, and declared that each state was independent and sovereign in itself. 44

Second, he argued that the Constitution itself was a kind of amendment to the Articles of Confederation, and thus was governed by the determination in Article II that "[e]ach State retains its sovereignty, freedom and independence. . . " 45 In the Constitution he found support for his theory: Article $V$ requires amendment by the states, Article III requires election of the president by states, and Article VII permits the Constitution to go into effect between ratifying states once nine have consented.

In almost every paragraph, the recurring theme asserts itself: These are sovereign States, voluntarily surrendering a part of their powers to a national government they themselves are creating. But the powers so surrendered are limited. . . . [a]nd lest there be any misunderstanding, it is firmly proclaimed that the powers not delegated by the Constitution to the United States, or prohibited by it to the States, are reserved to the States respectively, or to the people. 46

Kilpatrick next turned to the federal period. The first inspiration for his campaign came from the Virginia and Kentucky Resolutions that Madison and Jefferson produced in state legislatures to protest Federalist infringements on the First Amendment. These resolutions are generally held to have laid out the basic doctrine of interposition. ${ }^{47}$ "[W]e may well ask ourselves in 1955, confronting

42. Interposition at 35 (cited in note 12).

43. Kilpatrick, Sovereign States at 4 (cited in note 36) 36).

44. Interposition at 36 (cited in note 12); Kilpatrick, Sovereign States at 5 (cited in note

45. U.S. Articles of Confederation, Art. II; Kilpatrick, Sovereign States at 11 (cited in note 36).

46. Interposition at $\mathbf{2 5 - 2 6}$ (cited in note 12 ).

47. A careful and convenient historical summary of the arguments surrounding interposition and nullification, as they were framed at the time of the desegregation crises, can be 
a manifestly unconstitutional action not by the Congress but by the Supreme Court, whether the principles enunciated so forcefully by Jefferson and Madison may not have great validity today." 48 The Brown decision, as a "drastic . . . amendment of a clearly understood constitutional provision [was] a 'deliberate, palpable and dangerous' exercise by the court of authority not granted it[.]" 49 and as such should be resisted under the same authority as cited in the Resolutions.

Kilpatrick next cited as authority for interposition the dispute between Georgia and the Supreme Court as to whether the state could be named as a party to a suit by a citizen of another state. "[G]eorgia, in effect, invoked in 1792 the right of interposition: Georgia called upon all of the States to decide the issue. And in 1795, the States ratified the Eleventh Amendment by which Georgia was declared right, and the court wrong." so

In his newspaper editorials, Kilpatrick reprinted an excerpt from John C. Calhoun's Fort Hill Address, laying out the doctrine of nullification, 51 and he cited it approvingly in The Sovereign States.52 But he focused at least as much attention on the successful defiance by Wisconsin and other Northern states of Chief Justice Taney's decision in Ableman v. Booth.53 In this case, Wisconsin claimed the right to interpose its authority against enforcement of the Fugitive Slave Act. Taney, author of the Dred Scott decision, replied in sternly nationalistic language that because "the final appellate power [in disputes over the validity of an act of Congress] is given to this court, controversies as to the respective powers of the

found in Interposition vs. Judicial Power: A Study of Ultimate Authority in Constitutional Questions, 1 Race Relations L. Rptr. 465 (1956), which was written as a comment upon Kilpatrick's crusade and the legislative resolutions it inspired.

48. Interposition at 2 (cited in note 12) (emphasis in original).

49. Id.

50. Id. at 10 . This is the only recorded case that may be said to conform even remotely to Kilpatrick's model for resolution of conflicts between the states and the federal courts. But it is instructive to note the twist Kilpatrick has put on history. The proposed Eleventh Amendment declared Georgia right; had it failed of ratification, presumably Georgia would have been bound by the Court's interpretation. However, in the case of Brown, Kilpatrick inverted the process: Virginia would defy the court and consider itself vindicated unless the states ratified an amendment declaring it wrong. The difference in practical terms is obvious. No one ever doubted that Brown (or any other order of the Court) could lawfully be overturned by a Constitutional amendment. Under Kilpatrick's novel theory, it would be Brown itself that needed constitutional ratification, and if thirteen states voted against it (the Deep South plus border states in fact made up this number) the decision would be voided. In effect, a small group of states would be given an effective veto over the Court.

51. Id. at 12-15.

52. "To one reared in the custom of docile obedience to Federal authority, to the tradition of a strong 'national' government, Calhoun's cold and logical reasoning comes with the shock of an icy plunge." Kilpatrick, Sovereign States at 186 (cited in note 36).

53. 62 U.S. (21 How.) 506 (1859). 
United States and the States, instead of being determined by military and physical force, are heard, investigated, and finally settled, with the calmness and deliberation of judicial inquiry." 54 But Wisconsin still refused to comply. In Kilpatrick's sanitized summary of the aftermath, "the issue of contested power asserted by Wisconsin was ultimately to be resolved, so far as the Constitution is concerned, by constitutional amendment[.]"ss

In fact, the dispute of which Ableman v. Booth was a part was resolved by bloody civil war, of which the Thirteenth Amendment was only one result. And what is most intriguing in Kilpatrick's analysis of the growth of the Constitution is his remarkably narrow reading of the results of that conflict and the constitutional amendments that followed it.

To begin with, Kilpatrick concedes with ill grace that "the war, if it proved anything, proved that when one group of States is determined by force to contest the effort of another group of States to withdraw from the Union, law and sovereign rights are blown to the four winds and the issue is resolved on naked force alone." 56 But as for the three great amendments that follow it, he asks, "[in] what way ... did [they] alter the fundamental structure of the Union? And the answer, plainly, is in no way at all." 57 His explanation for this rather startling conclusion is laid out in detail in The Sovereign States, when he argues that if the victors in 1865 had truly wanted to create a national government,

[t]he steps toward that end should have been clear to a child's eye: To provide for a President, elected by a majority of all the people, wholly removed from State lines; to establish a Congress composed of Representatives from Federal districts according to national (not State) population; to rewrite Article V, in order to

54. Id. at 520 .

55. Interposition at 17 (cited in note 12). It is unusual to find Kilpatrick criticizing Chief Justice Taney, even by implication. In a career marked by tart criticism of many past and present Supreme Court decisions and judges, Kilpatrick has been unusually generous toward Taney's decision in Dred Scott. In Kilpatrick, Sovereign States at 211 (cited in note 36 ), he wrote that "[i]t is impossible to quarrel with" Taney's ruling that blacks could never be U.S. citizens, and that "its legal correctness has not been effectively challenged." He suggested that the Court's dictum suggesting that the federal government could not outlaw slavery was "one of the greatest judicial blunders in the Court's history," but, intriguingly enough in light of his devotion to states' rights, limited his criticism to the question of whether the issue was ripe for decision. Id. at 211-12. In fact, Dred Scott is not a decision of which a principled states' rights advocate could be expected to approve, since it implied that not even states could outlaw slavery.

56. Interposition at 10 (cited in note 12). Apparently in Kilpatrick's jurisprudence the Northern victory did not even establish that states have no right to secede. In Kilpatrick's view, the right itself seems to remain dormant, its exercise thwarted by Lincoln's illegal aggression.

57. Id. at 23 . 
make amendment of the Constitution a matter for the majority of the whole people; to skim through the Constitution, changing every plural reference to the United States to the singular; to wipe out the Tenth Amendment .... . Then, in fact, a national sovereignty would have been achieved, and the States would have been extinguished. 58

Since Congress did not enact this fanciful program, the amendments it did enact, he argued, could not change the basic contractual nature of the Constitution, nor limit states' rights; indeed, he finally dismissed the amendments as mere rhetorical flourishes that left states' rights not only extant but entirely unaffected: "no Reconstruction amendments or tricks of semantics can abridge them."59

Perhaps not surprisingly, Kilpatrick's exploration of constitutional history largely stops after the Civil War.60 It is, all told, an idiosyncratic and jumbled tour through American constitutional history. It is not necessary, three decades later, to refute it. Events, and the march of the law, have rendered most of Kilpatrick's arguments-and of the segregationist strategic thinking that lay behind them-moot, and exposed their fallacies.

It is worth imagining, however, what sort of country would exist if the existing Constitution had been replaced in 1956 with Kilpatrick's Constitution. It would be a country in which any state would hold veto power over the actions of the federal government, and in which the central government could function only if it could muster the support of three-fourths of the states. Citing the arguments of the Virginia-Kentucky Resolutions, Kilpatrick argued that "[o]nce the Federal Government were made to realize that its actions must have the approval of at least three-fourths of the States . . . the Federal Government could be expected to move circumspectly, within the fixed limits of the Constitution."61

Indeed, such a federal government could hardly be expected to "move" at all, and certainly not to take any controversial actions against, let us say, racial discrimination. In fact, Kilpatrick's Constitution looks rather remarkably like the Articles of Confederation, "unchanged by John Marshall, unchanged by the Civil War, not

58. Kilpatrick, Sovereign States at 223 (cited in note 36) (emphasis in original).

59. Interposition at 24 (cited in note 12).

60. Kilpatrick, Sovereign States (cited in note 36), devotes some space to a denunciation of the expansion of the commerce power, id. at 234-41 and 244-55, but devotes almost as much to an argument that the Fourteenth Amendment was never validly ratified, id. at 25877. Considering what a constitutional trifle Kilpatrick affected to consider a valid Fourteenth Amendment, one must wonder why he felt obliged to argue against its validity.

61. Interposition at 26 (cited in note 12). 
altered in any way since the Constitution was created in 1787,"62 and, indeed, unchanged by the Constitution itself. Truly, we are in the presence of the Constitution's shadow - of the tenuous, narrow, parochial and racist confederacy envisioned in the worst dreams of the worst antifederalists. One of Kilpatrick's most durable antagonists, Delegate Robert Whitehead, during the February 1956 debate on interposition, described on the floor of the House his own version of Kilpatrick's vision:

[T] he editor had a vision and dreamed a great dream. He saw the New Jerusalem-a land of 48 sovereign states, each separate and independent, composing what theretofore had been called the United States of America, and operating under a league or confederation like the one of old on the Balkan peninsula; and each judged for itself what was the law of the land; and he was pleased with the disorder of things, and solemnly resolved to call it home.63

Kilpatrick reached for a gavel, but ended up attacking the Constitution-and the nation-with an axe. Kilpatrick's lofty theoretical musings to the contrary notwithstanding, no one, at this remove of years (and indeed few even at the time) can be deceived that his motivation was the rawest sort of racism.

One reason Kilpatrick advanced for adopting interposition as state policy was that it would shift the debate away from race:

We who live in the South know clearly the sound reasons that support the wisdom of a dual society; we know, vividly and by first-hand experience, the gulf that divides the mores of two disparate races.

We know these things, but others do not know. . . . Virginia, by the adoption of [interposition], might succeed in elevating this controversy from the regional field of segregation to the transcendent, national field of State sovereignty. There is a tactical advantage in higher ground, and we would do well to seek it. 64

But regardless of tactics, the only issue in the fight was the place of blacks in the segregated South: "Already the Supreme Court ... has ordered an end to separate schools and parks. The next wind that blows from the court will take with it a State's power to prohibit interracial marriage."65

In The Sovereign States, Kilpatrick also tried to focus on the

62. Id. at 35 .

63. Gates, Making of Resistance at 114 (cited in note 11) (footnote omitted).

64. Interposition at 19 (cited in note 12).

65. Id. at 11 . 
"higher ground" of states' rights; but his mask occasionally slips here as well. "[I]n the South . . . the Negro race, as a race, has palpably different social, moral, and behavioral standards from those which obtain among the white race." What were these standards? Among blacks, he wrote, they were "bastardy," venereal disease, and crime.66 Little other contribution had been made to Southern society by blacks, because blacks were not capable of any other contribution: "[I]n no other part of the country has the industrious Negro advanced further, or progressed more rapidly, or been more rewarded for individual merit than in the Southern States. The pity is that the industrious are relatively so few."67

The covert racism of The Sovereign States is fully exposed and elaborated six years later in The Southern Case for School Segregation. Part I of that book, entitled "The Evidence," is not a constitutional argument, but a prolonged assault upon the very notion of black equality-indeed, in some senses, of black humanity. Kilpatrick's thesis is that

[i]n terms of enduring values-the kind of values respected wherever scholars gather, in the East no less than in the West-in terms of values that last, and mean something, and excite universal admiration and respect, what has man gained from the history of the Negro race? The answer, alas, is 'virtually nothing.' From the dawn of civilization to the middle of the twentieth century, the Negro race, as a race, has contributed no more than a few grains of sand to the enduring monuments of mankind.68

Kilpatrick's summary of "the evidence" features effusive praise for such "scientific" racists as Robert Gayre of Mankind Quarterly, Frank C.J. McGurk and Nathaniel Weyl, while dismissing the work of antiracist scholars such as Ashley Montagu, Otto Klineberg and Gunnar Myrdal as "no more than special pleading by propagandists against racial prejudice." 69

From this book wafts the unmistakable stench of another time: of "Impeach Earl Warren" billboards, of "sunset signs," of firehoses and dogs. For all its genteel air, it is the voice of the worst of the old South, written by an educated and persuasive advocate. It is the voice of a benighted people that, for all their talk of interposition and states' rights, worshiped, in the end, only at the altar of race.

66. Kilpatrick, Sovereign States at 279 (cited in note 36).

67. Id. at 281-82.

68. Kilpatrick, Southern Case at 49-50 (cited in note 2).

69. Id. at 70. A detailed examination of Kilpatrick's arguments appears in Newby, Challenge to the Court at 170-73 (cited in note 2). 
And if the old white South had race as its god, then surely James Kilpatrick aspired to be its prophet.

"I've come a long way," Kilpatrick told an interviewer in 1970. "Very few of us, I suspect, would like to have our passions and profundities at twenty-eight thrust in our faces at fifty." 70 That is as much of apology for his role in the making of "Massive Resistance" as the record discloses, and weak as it is, it is a dishonest one. Kilpatrick's attempt to dismantle the Constitution was not the work of a youth in his 20 s, but of a fully formed adult man of 35 , who had been a professional journalist for a decade and a half. It is perhaps not surprising that Kilpatrick should attempt to plead youth and inexperience, but the plea cannot stand.

Nor can his role be glossed over by arguing that most white Southerners believed in segregation and that Kilpatrick's role was simply that of a loyal son of his region. In fact, in the critical period after Brown, southern opinion was divided and confused. Many politicians and leaders expressed the cautious suggestion that, whatever the past merits of school segregation, the rule of law now required its abandonment. 71 History suggests that this would have been the wiser course, and that, had it been followed, the South today would be a richer, happier region. Further, had it been followed, many young lives blighted by poor education and racial hatred might have been spared that injury, and some who died by violence might still be alive. The decision to fight Brown was a fateful one, and, like many such decisions in Southern history, it was the work of a small but determined band of fanatics who imposed their bigotry on a confused society. Of that band of bigots, Kilpatrick was one of the most important.

History is the jury, and it will judge all of us-editors and scholars as surely as politicians and judges. And this jury may have grounds to judge James Kilpatrick more harshly than some of his contemporaries-and certainly more harshly than he has judged himself. At a time when the white South's response to her greatest modern challenge was in doubt, he bent every resource of his spirit and intellect to ensure that response would be harsh and defiant. He handed powerful racists a cloak behind which they might hide their racism and lawlessness. He took a bad situation and deliberately made it worse.

70. Current Biography Yearbook 1980 at 186 (cited in note 6). See also Michael Issikoff, Virginia Tradition: Richmond Editor Keeps Passions Stretched Tight in The Washington Post A1, col. 4, at A6, col. 5 (September 19, 1982) (" 'The News Leader was the intellectual leadership of massive resistance," " said Kilpatrick [in an interview conducted shortly before the article was published]. "No apologies for it." ")

71. Francis M. Wilhoit, The Politics of Massive Resistance 30-31 (Geo. Braziller, 1973). 
Of course, in so doing, he also strengthened both the constitutional doctrine of Brown and the functional supremacy of the Supreme Court as arbiter of the Constitution itself. $72 \mathrm{He}$ also helped write a new chapter in the history, still largely unwritten, of the Constitution's shadow.

72. See Cooper v. Aaron, 358 U.S. 1 (1958), the Court's stern but controversial response to the defiance of Governor Faubus. 